\title{
HARWELL RADIOCARBON MEASUREMENTS X
}

\author{
A J WALKER, A W YOUNG ${ }^{1}$ and $\mathrm{R}$ L OTLET \\ Isotope Measurements Laboratory, Harwell, Oxfordshire OX11 ORA UK
}

\section{INTRODUCTION}

This is the third of the series of lists of English archaeologic dates submitted to Harwell for measurement by the Historic Buildings and Monuments Commission for England and Wales within a prescribed contractual period. This list of 155 dates covers the period April 1987 to March 1988 and results are reported whether the associated projects are completed or on-going.

Measurement procedures were the same as reported in previous lists (eg, Walker, Williams \& Otlet 1990) with all three measuring systems of the Isotope Measurements Laboratory used as appropriate for the sample size and measurement precision required. The error term quoted is the 10 standard deviation estimate of the full replicate sample reproducibility (Otlet 1979). Calculations are based on the Libby half-life of 5568 years, using NBS oxalic acid standard as 'modern', both values treated as constants with $\mathrm{AD} 1950$ as the reference year. All results are corrected for fractionation according to the quoted $\delta^{13} \mathrm{C}$ (wrt PDB) values measured in the laboratory. National Grid Reference is abbreviated to NGR throughout.

\section{ACKNOWLEDGMENTS}

We wish to acknowledge the work of our colleagues DG Humphreys, J Fairchild and SA Charlesworth with the laboratory measurements. The financial support of the HBMC, which funded both the sample measurements and this publication, and the cooperation of the staff of the Ancient Monuments Laboratory, in particular D Haddon-Reece, is also gratefully acknowledged.

\section{ARCHAEOLOGIC SAMPLES}

HAR-941. ALF 2

$2540 \pm 70$

$\delta^{13} \mathrm{C}=-23.3 \%$

Bone, AML 749202, from northwest quadrant mound Layer 2 at Alfriston, Sussex. Coll and subm Oct 1974 by PL Drewett.

\section{Roxton series}

\section{HAR-1005. ROX74CQ3X1}

$2690 \pm 110$

$\delta^{13} \mathrm{C}=-25.8 \% 0$

Charcoal from point of stake pushed into ledge into which fireplace (HAR-1002, $3620 \pm 80$ ) (Otlet \& Walker 1979) was cut at Roxton, Bedfordshire $\left(52^{\circ} 9^{\prime} 50^{\prime \prime} \mathrm{N}, 0^{\circ} 19^{\prime} \mathrm{W}\right.$, NGR TL 156536). Coll by PJ Woodward and A Taylor and subm Jan 1975 by PJ Woodward, Trust for Wessex Archaeol.

Comment (PJW): sample was dated to clarify whether stake is representative of final phase of pit construction. Other dates are reported in Otlet and Walker (1979).

${ }^{1}$ Alleynes School, Stone, UK 
HAR-1647. WHC1V-5

$1150 \pm 100$

$\delta^{13} \mathrm{C}=-26.8 \%$

Charcoal from Layer 5, Barrow IV at West Heath Common. Subm June 1986 by H Keeley, Ancient Monuments Lab, London.

\section{Hambledon Hill series}

Charcoal samples from Neolithic Causewayed Enclosure, Hambledon Hill, Nr Blandford, Dorset $\left(50^{\circ} 54^{\prime} 27^{\prime \prime} \mathrm{N}, 2^{\circ} 13^{\prime} 3^{\prime \prime} \mathrm{W}\right.$, NGR ST 847121$)$. Coll and subm by RJ Mercer, Univ Edinburgh (Mercer 1980).

HAR-2369. HH7631

$$
\delta^{13} C=\begin{array}{r}
4520 \pm 80 \\
-22.6 \% \circ
\end{array}
$$

Hazelnut shells, identified by CA Keepax, AML 777003, from Layer 3, Site H, HH76, which consists of flint and chalk lumps set in dark-brown loam packed with crushed charcoal fragments and occasional burned shells. This is possibly scarp cut of causewayed enclosure ditch.

HAR-2370. HH7640

$5220 \pm 110$

$\delta^{13} \mathrm{C}=-24.9 \%$

Sample identified as oak, AML 777004, from Site G HH76, Segment 3, Layer 10. Deposit lies directly on solid floor of ditch.

HAR-6037. HN82C108

$4270 \pm 100$

AML 831452, from undercut.

$\delta^{13} \mathrm{C}=-25.8 \% 0$

\section{Beckford series}

Charcoal samples from Iron Age enclosure settlement at Beckford. Coll March and subm Aug 1978 by J Wills, Hereford and Worcester Co Mus.

\section{HAR-3097. BD65448}

$$
\begin{array}{r}
2440 \pm 90 \\
\delta^{13} C=-24.0 \% 0
\end{array}
$$

Sample identified by CA Keepax as oak (Quercus sp), hazel/alder (Corylus/Alnus sp), Rosaceae subfamily Pomoideae (eg, hawthorn) from mature timbers, AML 782077, from Iron Age gully enclosing roundhouse at Beckford.

HAR-4440. BD 54102

$1870 \pm 80$

Sample identified by CA Keepax as oak (Quercus sp) from mature timbers and hazel/alder (Corylus/Alnus sp) from twigs, from shallow ditch enclosing roundhouse.

\section{North Derbyshire series}

HAR-3339. U77C2F48

$$
\begin{array}{r}
1980 \pm 150 \\
\delta^{13} C=-26.6 \% \circ
\end{array}
$$

Charcoal, AML 780612, from hearth close to postholes from which carbonized grain was recovered at Unstone, Derbyshire. Coll and subm July 1979 by T Courtney. 
HAR-3969. BTS80501

$$
1020 \pm 80
$$

Bone from Bell Tout shaft. Coll and subm July 1980 by OR Bedwin. $\quad \delta^{13} C=-22.5 \% \circ$

\section{Kimpton series}

\section{HAR-4318. $X$}

Charcoal associated with human cremation inside urn of Middle Bronze Age date (Dacre \& Ellison 1981) from Bronze Age cremation cemetery at Kimpton (Kalis Corner), Hampshire. Subm Jan 1981 by AB Ellison, Trust for Wessex Archaeol.

\section{Ribchester series}

\section{HAR-4444. RB80-068}

$$
\begin{array}{r}
2800 \pm 110 \\
\delta^{13} C=-25.5 \% 0
\end{array}
$$

Charcoal, identified as Quercus sp, from primary vessel at Ribchester, Lancashire. Subm Feb 1981 by ACH Olivier, Univ Lancaster.

\section{HAR-4475. LFMBD4}

$6040 \pm 110$

$\delta^{13} \mathrm{C}=-27.1 \%$

Wood, identified as oak and birch, from lower part of gley podzol horizon developed on Folkestone Beds division of Lower Greensand at Longmoor Site I, E Hants (NGR SU787298). Coll summer 1979 and subm April 1981 by RM Jacobi, Univ Lancaster.

Comment (RMJ): associated with Mesolithic-type flint artifacts.

\section{Mingie's Ditch series}

\section{HAR-4488. HYMD136}

$1900 \pm 80$

$$
\delta^{13} \mathrm{C}=-27.2 \%
$$

Charcoal from base of Iron Age gully at Mingie's Ditch, Hardwick-with-Yelford, Oxon $\left(51^{\circ} 45^{\prime} 0^{\prime \prime} \mathrm{N}, 1^{\circ} 26^{\prime} 1^{\prime \prime} \mathrm{W}\right.$, NGR SP 391059). Coll and subm May 1981 by MA Robinson, Univ Museum, Oxford.

\section{Charlwood Site I series}

Charcoal samples from lower levels of pit excavated into Weald clay containing Mesolithic flint artifacts and calcined bone at Charlwood Site I. Coll Dec 1979 and subm April 1981 by RL Ellaby.

\section{HAR-4531. PIT11214}

$4340 \pm 100$

AML 820433, from level $30-35 \mathrm{~cm}$.

$\delta^{13} \mathrm{C}=-28.3 \%$

HAR-4532. PIT11416

$$
5270 \pm 90
$$

AML 820432, from level $35-40 \mathrm{~cm}$.

$$
\delta^{13} \mathrm{C}=-27.3 \%
$$

HAR-4533. PIT11618

$$
5640 \pm 90
$$

AML 820431, from level $40-45 \mathrm{~cm}$.

$$
\delta^{13} \mathrm{C}=-26.3 \%
$$


Oxford St Aldates series

HAR-5342. OXTMS29

$$
\begin{array}{r}
2410 \pm 80 \\
\delta^{13} C=-28.6 \% 0
\end{array}
$$

Wood from silting of primary channel at 89-91 St Aldates, Oxford $\left(50^{\circ} 41^{\prime} 55^{\prime \prime} \mathrm{N}, 2^{\circ} 32^{\prime} 54^{\prime \prime} \mathrm{W}\right.$, NGR SY 61288898). Coll and subm Oct 1982 by BG Durham, Oxford Archaeol Unit. Other dates from site are reported in Walker, Williams and Otlet (1990). Site is described in Durham (1977, 1984).

\section{Claydon Pike series}

HAR-5409. FCP3

$1640 \pm 70$

$\delta^{13} \mathrm{C}=-20.9 \%$

Bone, from lower levels of latest Iron Age enclosure on this "island" (Phase 4) at Claydon Pike, Lechlade, Gloucestershire. Coll and subm Oct 1983 by David Miles.

Comment (DM): enclosure was cut by post-Medieval features containing whole skeletons, and some later bone fragments may have penetrated lower levels.

Raunds series

HAR-5494. 6635-246

$$
\delta^{13} C=\begin{array}{r}
940 \pm 90 \\
-26.4 \% 0
\end{array}
$$

Charcoal, AML 830753, from fill of posthole at Raunds, Northants $\left(52^{\circ} 20^{\prime} 54^{\prime \prime} \mathrm{N}, 0^{\circ} 32^{\prime} 0^{\prime \prime} \mathrm{W}\right.$, NGR SP 999733). Coll and subm Sept 1983 by Graham Cadman, Northamptonshire Co Council. For description of site, see Boddington and Cadman (1981) and Cadman (1983).

HAR-5509. 241-088

$1000 \pm 80$

$$
\delta^{13} \mathrm{C}=-25.7 \% \text { o }
$$

Charcoal (Quercus sp) associated with Long Barrow at Stoke Bishop, Bristol. Coll and subm Feb 1983 by N Balaam.

\section{Upper Walls Common series}

HAR-5964. UWCA2224

$$
\begin{array}{r}
1990 \pm 110 \\
\delta^{13} C=-21.0 \%
\end{array}
$$

Bone from primary silt of major north-south ditch of large agricultural enclosure at Baldock Upper Walls Common, northeast of Baldock (51 $59^{\prime} 24^{\prime \prime} \mathrm{N}, 0^{\circ} 10^{\prime} 46^{\prime \prime} \mathrm{W}$, NGR TL 250340 ). Coll and subm Sept 1983 by GR Burleigh.

Comment: provides starting date for series of intersecting enclosures and, hence, dates subdivision of the land around Late Iron Age/Roman settlement for agricultural purposes and also helps narrow date range of associated pottery.

\section{HAR-6400. UU280}

$$
\begin{array}{r}
4930 \pm 100 \\
\delta{ }^{13} C=-21.4 \% \circ
\end{array}
$$

Bone, cattle vertebra, AML 842044, from Hoe Hill Long barrow, Swinhope, Lincolnshire $\left(53^{\circ} 26^{\prime} 57^{\prime \prime} \mathrm{N}, 0^{\circ} 10^{\prime} 13^{\prime \prime} \mathrm{W}, \mathrm{NGR}\right.$ TF 215963$)$. 
Comment (PP): result is compatible with expected Early Neolithic construction or immediate post-construction date of long barrow (Phillips 1989).

\section{Stanch Meadow series}

Peat samples from base of section at Stanch Meadow, Brandon, Suffolk $\left(52^{\circ} 26^{\prime} 53^{\prime \prime} \mathrm{N}\right.$, $0^{\circ} 37^{\prime} 5^{\prime \prime} E$, NGR TL 779866). Coll and subm Aug 1984 by P Murphy, Univ East Anglia.

HAR-6474. BRD0185B

AML 841429.

HAR-6475. BRD0185A

AML 841428.

$$
\begin{array}{r}
1920 \pm 60 \\
\delta^{13} C=-30.9 \% 0 \\
1950 \pm 70 \\
\delta^{13} C=-31.0 \% 0
\end{array}
$$

General Comment (PM): samples also taken from peat column for pollen and macrofossil analysis to provide information on local vegetational change. Middle Saxon pottery found in upper part of peat (Carr, Tester \& Murphy 1988).

\section{Stow Church series}

Charcoal and bone from Stow Church, Lincolnshire. Coll and subm Nov 1984 by Trust for Lincs Archaeology.

HAR-6748. ST83270B

$$
\begin{array}{r}
1100 \pm 40 \\
\delta^{13} C=-28.9 \% \circ
\end{array}
$$

Charcoal, AML 858539, from floor of Saxon aisle, destruction layer of building antedating porticus which both antedates burials (eg B51) and postdates them (eg B78).

Comment (NF): may represent earlier church; important phase in development of site.

HAR-6749. 844219

$$
\begin{array}{r}
1410 \pm 80 \\
\delta^{13} C=-27.1 \% \circ
\end{array}
$$

Charcoal, AML 858538, from floor of Saxon aisle, destruction layer of building antedating porticus which both antedates burials (eg B51) and postdates them (eg B78).

Comment (NF): may represent an earlier church; important phase in development of the site.

HAR-8332. ST83B51

Bone, AML 858540, from B51, latest burial in sequence.

HAR-8333. ST83B78

Bone, AML 858536, from B78, earliest burial in sequence.

HAR-8809. ST83/62

Bone, identified as cattle, AML 844227.

$$
1270 \pm 40
$$$$
\delta^{13} \mathrm{C}=-21.7 \%
$$

$1190 \pm 30$

$\delta^{13} \mathrm{C}=-20.8 \%$

$960 \pm 80$

$\delta^{13} \mathrm{C}=-22.0 \%$ 
HAR-8810. ST83/31

$960 \pm 70$

HAR-8812. ST83/61

$\delta^{13} \mathrm{C}=-21.8 \% 0$

Left leg, AML 844225.

$930 \pm 60$

$\delta^{13} \mathrm{C}=-21.4 \%$ 。

HAR-8813. ST83/58

$930 \pm 60$

AML 844223.

$\delta^{13} \mathrm{C}=-21.7 \%$ 。

HAR-8815. ST83/70

$1200 \pm 60$

Identified as right leg, AML 844228.

$\delta^{13} \mathrm{C}=-21.5 \%$

\section{Haddenham series}

Samples from Upper Delphs Terrace, Haddenham, Cambridgeshire $\left(52^{\circ} 20^{\prime} 21^{\prime \prime} \mathrm{N}, 0^{\circ} 4^{\prime} 17^{\prime \prime} \mathrm{E}\right.$, NGR TL 411733). Coll Sept 1985 and Jan 1986 and subm May 1987 by C Evans, Univ Cambridge. Site is described in Evans (1986) and Evans and Serjeantson (1988).

HAR-8092. HAD84I

Charcoal.

$$
\begin{array}{r}
4970 \pm 90 \\
\delta^{13} C=-27.0 \%
\end{array}
$$

HAR-8094. HAD84-IV

$$
3620 \pm 110
$$

Charcoal.

$$
\delta^{13} \mathrm{C}=-25.0 \%
$$

\section{HAR-8764. HV2655}

$2110 \pm 70$

$\delta^{13} C=-27.1 \%$

Charcoal, AML 874394, from pit associated with pre-enclosure Building 3 - definitely sealed by main Round House 4 at HAD V.

Comment (CE): dates pre-enclosure occupation of site (Iron Age).

HAR-8765. HV2289

$1990 \pm 60$

$\delta^{13} \mathrm{C}=-27.3 \%$

Wood, AML 874395, from brushwood in base of main enclosure ditch sealed by dumped (secondary) gravel causeway at HAD V.

Comment (CE): dates construction of ditched yard enclosure (Iron Age).

HAR-8766. HV2735

$$
\begin{array}{r}
2000 \pm 60 \\
\delta^{13} C=-25.4 \% 0
\end{array}
$$

Wood, AML 874396, from burned post from destruction of main Round House 4 at HAD V.

HAR-8767. 16351679

$1970 \pm 60$

$\delta^{13} \mathrm{C}=-28.5 \%$

Wood, AML 874397, from uppermost organic fill of main enclosure ditch (F95) in direct 
association with articulated skeleton of common crane at HAD V.

Comment (IH): dates 1) final usage/abandonment of ditched enclosure and onset of freshwater flooding, and 2) skeleton of juvenile common crane. The latter is of great zoological value as it throws light on crane breeding areas in prehistory (M Northcote, pers commun).

\section{Beeston Castle series}

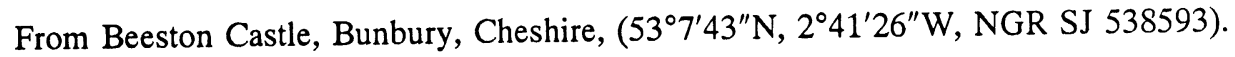

HAR-8102. BEE2BAH

$$
\begin{array}{r}
2480 \pm 70 \\
\delta^{13} C=-28.3 \% \circ
\end{array}
$$

Soil, AML 841463, from onset of secondary ditch fill (NGR SJ 550610). Coll Oct 1983 and subm Nov 1984 by RI MacPhail, Institute of Archaeol London.

Comment (RIM): result dates major standstill phase in soil pollen sequence.

\section{HAR-8182. TBD8ANTL}

Antler, AML 8650175, from primary silts of ditch: Trench D, Context 8 at Thundersbarrow Hill, Shoreham, West Sussex $\left(50^{\circ} 51^{\prime} 45^{\prime \prime} \mathrm{N}, 0^{\circ} 15^{\prime} 12^{\prime \prime} \mathrm{W}\right.$, NGR TQ 229085). Coll and subm Sept 1986 by CR Cartwright, Institute Archaeol, London.

Comment (LCS): antler was recovered from floor of ditch sealed by primary fills, Context 8 . Although date of inner enclosure ditch is thought to be late Bronze Age on basis of pottery from upper layers of Ditch C, Contexts 2 and 4, antler remains only dating source for construction and primary use and its primary fills.

\section{Buckskin II series}

Samples from Buckskin II, Site I (Bell Barrow), Basingstoke, Hampshire $\left(50^{\circ} 18^{\prime} 40^{\prime \prime} \mathrm{N}\right.$, $5^{\circ} 21^{\prime} 55^{\prime \prime} \mathrm{W}$, NGR SW 60435118 ). Coll $1967 / 8$ by B Applin and subm by M Morris, Winchester Archaeol Office.

\section{HAR-8371. 2BS137}

Fine charcoal and soil, AML 8650024, from F137, ritual pit containing cremated human bone and located toward periphery of mound.

Comment (MM): pit may be a secondary insertion, result provides chronologic relationship with barrow mound and pre-barrow features.

HAR-8372. 3BS137

$3220 \pm 130$

$\delta^{13} \mathrm{C}=-26.8 \%$

Soil, AML 8650025, from F137 a "ritual" pit containing cremated human bones, located toward the periphery of the mound.

Comment (MM): it is unclear if this was secondary burial; result establishes chronologic relationship with barrow mound and pre-barrow features. 
HAR-8374. 5BS21

$4360 \pm 90$

Charcoal, AML 8650027, from mound core material of Layer 21.

$\delta^{13} \mathrm{C}=-28.0 \%$

Comment (MM): dates mound construction, in absence of artifacts, and use period of site as
funerary monument.

\section{Heslerton Parish series}

Bone and charcoal samples from multi-phase site in Heslerton Parish, Vale of Pickering, Yorkshire $\left(54^{\circ} 10^{\prime} 40^{\prime \prime} \mathrm{N}, 0^{\circ} 35^{\prime} 36^{\prime \prime} \mathrm{W}\right.$, NGR SE 918767). Subm Oct 1984 by DJ Powesland, Heslerton Project. Other dates are reported in Walker, Williams and Otlet (1990).

HAR-8413. HPOOO15C

Bone, AML 841215, from Context IMO0365.

$$
3440 \pm 60
$$

$\delta^{13} \mathrm{C}=-22.3 \%$

HAR-8414. HP00019C

$$
\begin{array}{r}
2980 \pm 80 \\
\delta^{13} C=-23.1 \% \circ
\end{array}
$$

Bone, identified as infant, 2 to 4 years old, AML 841219, from IR299, burial in Early Bronze Age barrow with bronze object and flint blade.

HAR-8415. HPOOO18C

$$
\begin{array}{r}
3470 \pm 60 \\
\delta^{13} C=-22.3 \% 0
\end{array}
$$

Bone, AML 841218, from Context 1R272, burial from Early Bronze Age barrow with an undecorated beaker and a copper or bronze awl.

\section{HAR-8416. HPOOO10C}

Charcoal, AML 841210, from Context IKOOO55.

$$
\begin{array}{r}
4010 \pm 80 \\
\delta^{13} C=-25.8 \% 0 \\
2780 \pm 80 \\
\delta^{13} C=-26.1 \% 0
\end{array}
$$

HAR-8417. HPOOO11C

Charcoal, AML 841211, from domestic rubbish pit containing large assemblage of StapleHowe-type pottery.

General Comment: Vale of Pickering was previously believed of minor importance in Early Bronze Age compared with the Wolds, but new evidence, in particular ${ }^{14} \mathrm{C}$ dates for Beaker burials, shows this to be untrue.

\section{Blackwater series}

Samples from wooden structures on foreshore at Goldhanger, Essex, (Site 28), (51 $41^{\circ} 52^{\prime \prime} \mathrm{N}$, $0^{\circ} 45^{\prime} 13^{\prime \prime} E$, NGR TL90140725). Coll Aug and subm Sept 1986 by P Murphy, Univ East Anglia (except HAR-8880, -8881 coll July and subm Oct 1987).

HAR-8457. B28121

AML 8650293, formerly sealed beneath estuarine sediments.

$$
2220 \pm 60
$$

$\delta^{13} \mathrm{C}=-27.7 \%$ 
HAR-8458. B28126

$2380 \pm 70$

AML 8650294, formerly sealed beneath estuarine sediments.

$\delta^{13} \mathrm{C}=-27.7 \%$

HAR-8459. B28127

$240 \pm 60$

AML 8650295.

$\delta^{13} \mathrm{C}=-27.6 \%$

HAR-8460. B28128

$250 \pm 60$

AML 8650296.

$\delta^{13} \mathrm{C}=-30.0 \%$

HAR-8461. B28129

$2300 \pm 60$

AML 8650297, formerly sealed beneath estuarine sediments.

$\delta^{13} \mathrm{C}=-27.8 \%$

HAR-8880. B28/190

$2400 \pm 60$

AML 878289, from estuarine clays.

$\delta^{13} \mathrm{C}=-29.1 \% 0$

HAR-8881. B28/195

$2080 \pm 70$

$\delta^{13} \mathrm{C}=-30.5 \% 0$

AML 878290, from wooden hurdle on upper foreshore of estuarine clays.

General Comment (PM): samples, exposed by tidal erosion, were first located in 1985. Dating through stratigraphy is impossible, and no artifacts were found. Late prehistoric date was suggested by elevation and analogy with other ${ }^{14} \mathrm{C}$ dates, but results indicate multi-component site of greater complexity than originally thought (Wilkinson \& Murphy 1986, 1988).

\section{Abington Pigotts series}

Wood (identified as Quercus sp) from Abington Pigotts, Downhall Gatehouse, Cambridge $\left(52^{\circ} 4^{\prime} 33^{\prime \prime} \mathrm{N}, 0^{\circ} 5^{\prime} 49^{\prime \prime} \mathrm{W}\right.$, NGR TL 304437). Coll and subm Sept 1986 by D Sherlock, Hist Bldgs and Monuments Commission.

HAR-8505. AP86-2

$730 \pm 30$

AML 8650143, from west gable tie beam of late Medieval gatehouse. $\quad \delta^{13} C=-25.1 \% 0$

HAR-8506 AP86-3

$780 \pm 40$

AML 8650143, from west gable tie beam of late Medieval gatehouse. $\quad \delta^{13} C=-25.8 \%$ o

\section{Hemington Fields series}

Wood samples from abandoned floodplain and gravel pit at Castle Donington, Leicestershire $\left(52^{\circ} 52^{\prime} 1^{\prime \prime} \mathrm{N}, 1^{\circ} 19^{\prime} 13^{\prime \prime} \mathrm{W}\right.$, NGR SK 45753020). Coll Sept 1986 and subm April 1987 by CR Salisbury. Site at Castle Donington and its relationship to River Trent are detailed in Salisbury $(1984,1988)$ and Clay and Salisbury $(1990)$. Other results are reported in Walker, Williams and Otlet (1990).

HAR-8507. PL8FWA86

$$
\begin{array}{r}
1280 \pm 70 \\
\delta^{13} C=-26.3 \% \circ
\end{array}
$$

Oak, 17 rings of heartwood, AML 872587, from post buried in abandoned river bed in clean 
gravel 1-3m below gravel/overburden (silt) interface in gravel pit, $5.5 \mathrm{~m}$ deep.

Comment (CRS): sample is 1 of line of 13 posts, probably fish weir associated with Norman dam, $130 \mathrm{~m}$ upstream, linking abandoned river channel. Wood was not re-used and can confidently be used to date channel and artifacts found therein, eg, anchor stones, querns and pieces of clinker built boat.

\section{HAR-8508. PL7FWB86}

Purging buckthorn, trunk with bark, 56 rings, AML 872586, from post $2.5 \mathrm{~m}$ below gravel $/ \mathrm{silt}$ overburden interface on bed of abandoned river channel in gravel pit, $5.5 \mathrm{~m}$ deep.

Comment (CRS): 1 of 9 posts, mostly buckthorn. Associated wattlework suggests this was fish weir. Although only $120 \mathrm{~m}$ from Norman dam and fish weir in similar abandoned channel, this must be earliest fish weir in UK.

\section{HAR-8509. PLIPST85}

$$
\begin{array}{r}
1150 \pm 70 \\
\delta^{13} C=-28.7 \% \circ
\end{array}
$$

Hazel, ca 30 rings, AML 872585, from five adjacent vertical posts driven into old river bed, now buried in gravel pit under $2 \mathrm{~m}$ of clean gravel and $1 \mathrm{~m}$ of silt overburden.

Comment (CRS): sample is part of line of 22 posts, some wattled, probably a fish weir. Posts were aligned with and beneath Norman mill dam, dated AD 1120 by dendrochronology. Weir would have obstructed river flow to form sand bank on which mill dam was constructed. (Structure originally was assumed to be Bronze Age.)

\section{South West Fen Survey series}

Peat and charcoal from two sites were investigated by the Fenland Archaeological Trust as part of the South West Fen Dyke Survey (French \& Pryor, in press).

\section{HAR-8512. SWFC3}

$$
\begin{array}{r}
2090 \pm 80 \\
\delta^{13} C=-26.7 \% \circ
\end{array}
$$

Charcoal, from sealed "occupation" deposit, beneath alluvium and in ringfort on fen edge, NW Cambridgeshire at Borough Fen Site 7 (52 $37^{\prime} 48^{\prime \prime} \mathrm{N}, 0^{\circ} 50^{\prime} 14^{\prime \prime} \mathrm{E}$, NGR TF 920 0740). Coll Nov 1983 and subm March 1987 by C French, Fenland Archaeol Trust.

Comment (CF): date ranges corroborate middle/late Iron Age date already obtained from pottery. West $2 / 3$ of site is scheduled monument; east $1 / 3$, from which dating material was recovered, is unscheduled and being eroded by plowing. Ringfort is only known site of its kind and date in NW Cambridgeshire (French \& Pryor, in press; French 1988).

\section{HAR-8513. SWFC4}

Peat, from base of lower peat at Crowtree Farm, Cambridgeshire (NGR TF 52133061). Coll Feb 1985 and subm April 1987 by CF.

Comment (CF): temporary occupation site of Late Neolithic/Early Bronze Age on Fen edge peninsula, overlapped by lower peat. 


\section{Lofts Farm series}

Charcoal samples from Lofts Farm, Blackwater Estuary, East Essex $\left(51^{\circ} 45^{\prime} 4^{\prime \prime} \mathrm{N}, 0^{\circ} 42^{\prime} 29^{\prime \prime} \mathrm{E}\right.$, NGR TL86900936), a sub-rectangular enclosure on low-lying gravels bordering estuary (Brown 1988). Coll Jan 1985 and subm April 1987 by P Murphy, Univ East Anglia.

\section{HAR-8514. LFP1002}

$$
\begin{array}{r}
\mathbf{2 6 8 0} \pm \mathbf{7 0} \\
\delta^{13} C=-26.5 \% 0
\end{array}
$$

AML 873577, from upper fill of well, $2 \mathrm{~m}$ deep, outside and south of enclosure.

Comment (PM): sample came from fill of dark silt loam with much domestic debris, apparently deliberate backfilling of well and markedly different from lower layer - largely artifact-free organic silt clay. Context produced large assemblage of Darmsden-Linton pottery, ceramic style known from other East Anglian sites and typologically Iron Age.

HAR-8515. LF840192

$$
\begin{array}{r}
2460 \pm 70 \\
\delta^{13} C=-30.6 \% 0
\end{array}
$$

AML 873576, from upper fill of enclosure ditch.

Comment (PM): sample provides date for associated Late Bronze Age pottery and last use of enclosure. Together with dates for upper and lower fills of well, it provides chronologic framework for interpretation of site.

\section{HAR-8521. LFP8402}

$2800 \pm 110$

$\delta^{13} \mathrm{C}=-27.8 \%$ 2).

Wood, oak (Quercus sp), AML 872540, from stake from base of Late Bronze Age well (Stake

Comment (PM): purpose of dating was twofold: 1) to date feature and associated pottery and 2) for chronologic framework for tree-ring studies. Researchers hope to establish local ring sequence using this wood and LBA wood from intertidal structures (Hullbridge Survey).

\section{Cot Nab series}

\section{HAR-8516. CNRBG2}

$3530 \pm 140$

$\delta^{13} \mathrm{C}=-22.3 \%$ 。

Bone, identified as human, left tibia and femur, AML 8650262, from Grave 2 which cuts and thus postdates Grave 1 at Cot Nab (Garrowby Wold 104), Kirby Underdale, North Yorkshire $\left(54^{\circ} 0^{\prime} 5^{\prime \prime} \mathrm{N}, 0^{\circ} 45^{\prime} 12^{\prime \prime} \mathrm{W}, \mathrm{NGR}\right.$ SE 817569$)$. Coll and subm March 1987 by AE Finney, East Riding Archaeol Comm.

Comment (AEF): stratigraphic details are insufficient to show whether both graves postdate mound. Their positions in relation to mound suggest, 1) both Bronze Age secondary burials, 2) both postdate barrow, or 3) Grave 1 is Bronze Age and Grave 2 is later, possibly Anglian.

\section{Sharpe Howes series}

From Sharpe Howes 2 (Folkton 240), Folkton Wold, Folkton East Yorkshire $\left(54^{\circ} 10^{\prime} 14^{\prime \prime} \mathrm{N}\right.$, $0^{\circ} 17^{\prime} 20^{\prime \prime}$ E, NGR TA 494774). Coll Aug 1967 by TCM Brewster and subm March 1987 by AE Finney, East Riding Archaeol Research Comm. 
HAR-8518. SHB2WQ

Antler, identified as red deer, AML 8650259 , from primary silting of west quarry.

Comment (AEF): no associated pottery to date mound was found in either 1888 or 1967 excavations.

\section{HAR-8519. SHB4G1}

$$
\begin{array}{r}
3800 \pm \mathbf{7 0} \\
\delta^{13} C=-22.5 \% \circ
\end{array}
$$

Bone, identified as human, right tibia and femur, AML 8650260, from central grave.

Comment (AEF): barrow was badly plow-damaged and central grave disturbed; no associated finds.

General Comment: three dates provide chronologic framework for site and serve to tie it into extensive series of Late Bronze Age and Early Iron Age ${ }^{14} \mathrm{C}$ dates obtained from submerged sites in the Blackwater estuary and elsewhere along the Essex coast.

HAR-8520. 72391137

$$
\begin{array}{r}
3870 \pm 70 \\
\delta^{13} C=-25.8 \% 0
\end{array}
$$

Charcoal, AML 872720, from lower filling of pit truncated by mechanical stripping of topsoil and subsoil and containing Beaker sherds and flints at Longham, Norfolk $\left(52^{\circ} 43^{\prime} 1^{\prime \prime} \mathrm{N}, 0^{\circ} 51^{\prime} 35^{\prime \prime} \mathrm{E}\right.$, NGR TF 93131713). Coll July 1985 by G Joyce and subm by J Wymer, Norfolk Archaeol Unit.

Comment (JW): dates spread of domestic beaker material adjacent to excavated mound with inverted beakers.

\section{Alcester series}

Wood samples from Site AL 18, Alcester, Warwickshire. Coll by S Cracknell and subm March 1987 by J Hillam, Univ Sheffield.

HAR-8522. 628A

$$
\begin{array}{r}
1730 \pm 40 \\
\delta^{13} C=-29.1 \% 0
\end{array}
$$

Wood, AML 872593 (identified as Quercus sp) from Context 628, foundation trench of mid4 th century town wall.

Comment (JH): 55 -year old sample; outer 20 rings were dated.

HAR-8523. 628C

$$
1700 \pm 40
$$

$\delta^{13} \mathrm{C}=-27.5 \%$

Wood, AML 872594 (identified as Quercus sp) from Context 628, foundation trench of mid4 th century town wall.

Comment (JH): 45-year-old stem; outer 20 rings were dated.

HAR-8524. 861J

$$
\delta^{13} \mathrm{C}=-28.2 \%
$$

Wood, alder (Alnus glutinosa Gaertn), AML 872595, from Context 861, foundation trench for 
bastion added to town wall in late 4th century.

Comment (JH): sample was 41 years old.

HAR-8525. 861G

$1710 \pm 40$

$\delta^{13} \mathrm{C}=-30.2 \%$

Wood, alder (Alnus Glutinosa Gaertn), AML 872596, from Context 861, foundation trench for the bastion added to town wall in late 4th century.

Comment (JH): sample was 37 years old.

Tattershall Thorpe series

Samples are from lower levels of enclosure ditch at Tattershall Thorpe, Lincs. Coll and subm March 1987 by P Chowne, Trust for Wessex Archaeol.

HAR-8527. TT86204

$2210 \pm 70$

AML 872565.

$\delta^{13} \mathrm{C}=-28.9 \%$

Comment (PC): dates enclosure.

HAR-8528. TT86151

$990 \pm 70$

AML 872566.

$\delta^{13} C=-27.4 \%$

Comment (PC): dates enclosure.

HAR-8529. TT86226

$410 \pm 70$

AML 872564.

$\delta^{13} \mathrm{C}=-27.7 \%$

Comment (PC): dates construction and use of enclosure.

HAR-8530. TT8615

$1940 \pm 80$

AML 872567 from hearth.

$\delta^{13} \mathrm{C}=-28.0 \%$ 。

Comment (PC): dates secondary site use.

\section{Bain Valley Project}

HAR-8531. LT07861

$1530 \pm 70$

$\delta^{13} \mathrm{C}=-26.8 \%$

Charcoal, AML 872568, from filling of Neolithic hearth, associated with pottery and animal bone at Low Toynton, Bain Valley. Coll and subm March 1987 by P Chowne.

Comment (PC): dates Neolithic activity in middle Bain Valley and compares with Tattershall Thorpe dates.

\section{Hayling Island Saxon series}

Charcoal samples from Hayling Island Iron Age and Roman Temple, Hayling Island, Hants $\left(50^{\circ} 49^{\prime} 20^{\prime \prime} \mathrm{N}, 0^{\circ} 58^{\prime} 19^{\prime \prime} \mathrm{W}, \mathrm{NGR}\right.$ SU 724 031). Coll 1977 and subm April 1986 by G Soffe, Royal Comm Hist Monuments (England). 
HAR-8532. K3

$$
\begin{array}{r}
1270 \pm 90 \\
\delta^{13} C=-25.3 \% 0
\end{array}
$$

AML 872582, from shallow ditch overlying Roman Temple, associated with Mid-Saxon pottery.

HAR-8533. E98/99

$2230 \pm 120$

$\delta^{13} \mathrm{C}=-25.7 \% 0$

AML 872581, from burned timber post forming part of entrance to temple.

Comment (GS): dates construction and use of Iron Age temple.

HAR-8534. E39A

$1910 \pm 70$

$\delta^{13} \mathrm{C}=-26.5 \%$

AML 872580 from pit in center of temple, associated with metalwork, unusual forms of pottery and Celtic coins.

Comment (GS): dates construction and use of Iron Age temple.

HAR-8535. E46

$1840 \pm 100$

$\delta^{13} \mathrm{C}=-25.9 \%$

AML 872579 from Late Iron Age gully forming part of circular structure of temple, associated with unusual forms of pottery and Celtic coins.

Comment (GS): dates construction and use of Iron Age temple.

HAR-8536. V57A/1

$1440 \pm 90$

$\delta^{13} C=-26.4 \%$ 。

AML 872583, from part of burned plank at base of mid-Saxon pit dug into courtyard of Roman temple.

HAR-8537. V57A/2

$1720 \pm 100$

$\delta^{13} \mathrm{C}=-26.3 \%$

AML 872584, from base of mid-Saxon pit dug into courtyard of Roman temple.

Wetwang Slack series

HAR-8541. WC5AO

$1310 \pm 70$

$\delta^{13} \mathrm{C}=-28.2 \%$

Charcoal, AML 872563, from a pit in "grubenhaus"-like feature at Wetwang Slack, Wetwang, Humberside ( $54^{\circ} 1^{\prime} 38^{\prime \prime} \mathrm{N}, 0^{\circ} 33^{\prime} 48^{\prime \prime} \mathrm{W}$, NGR SE 941600). Coll and subm March 1987 by J Dent.

Comment (JSD): this feature was dated on typological grounds to Anglo-Saxon period (Dent 1983).

\section{Brean Down series}

Charcoal and bone samples from Brean Down Sandcliff, Brean Nr Burnham on Sea, Somerset. Coll and subm April 1987 by M Bell, St David's Univ Coll, Lampeter. 


\section{HAR-8547. BDUB556}

$$
\begin{array}{r}
3460 \pm 80 \\
\delta^{13} C=-28.3 \% \circ
\end{array}
$$

Charcoal (identified as Quercus sp, Prunus spinosa, Pomoideae, hawthorn, etc) from pit dug in surface of Unit 8a (Neolithic and Beaker) at Brean Down $\left(51^{\circ} 19^{\prime} 24^{\prime \prime} \mathrm{N}, 3^{\circ} 0^{\prime} 38^{\prime \prime} \mathrm{W}\right.$, NGR ST296588).

Comment (MGB): When examined by H Taylor in 1936, pit contained two Beaker pots and was interpreted as a burial. Sample dates Beaker pots and also helps establish date of Beaker activity within Brean sequence as a whole (ApSimon, Donovan \& Taylor 1961; Taylor \& Taylor 1949; Bell 1986, 1990).

HAR-8548. BD6530

$1550 \pm 80$

$\delta^{13} \mathrm{C}=-20.0 \%$

Bone from Context 213, part of sub-Roman cemetery lying within Unit 3 at Brean Down $\left(51^{\circ} 19^{\prime} 21^{\prime \prime} \mathrm{N}, 3^{\circ} 0^{\prime} 43^{\prime \prime} \mathrm{W}\right.$, NGR ST 295587).

Comment (MGB): dates phase of activity and helps establish chronologic range of sub-Roman cemetery.

HAR-8549. BD6543

$1430 \pm 70$

$\delta^{13} \mathrm{C}=-22.7 \%$

Bone, identified as tibiae, fibulae and femora of human skeleton, from Context 212, part of sub-Roman cemetery at Brean Down $\left(51^{\circ} 19^{\prime} 21^{\prime \prime} \mathrm{N}, 3^{\circ} 0^{\prime} 43^{\prime \prime} \mathrm{W}\right.$, NGR ST295587).

Comment (MGB): grave marked by massive limestone boulder and revetted by limestone slabs on up-side. It was orientated east-west and without grave goods.

\section{Bidford on Avon series}

Bone from Bidford Site VII, Bidford on Avon, ( $52^{\circ} 10^{\prime} 0^{\prime \prime} \mathrm{N}, 1^{\circ} 51^{\prime} 3^{\prime \prime} \mathrm{W}$, NGR SP 102521). Coll and subm July 1987 by S Hirst.

\section{HAR-8576. HB9B}

$1150 \pm 70$

$\delta^{13} \mathrm{C}=-19.9 \%$

AML 874399, from same context as HB9A but thought to have been buried longer.

HAR-8577. HB9A

$1650 \pm 80$

$\delta^{13} C=-21.3 \%$ 。

Bone, AML 874398, from same context as HB9B but thought to be younger.

\section{Dorchester By-Pass series}

HAR-8578. 18338244

$$
\begin{array}{r}
4030 \pm 100 \\
\delta^{13} C=-23.6 \% \circ
\end{array}
$$

Antler, identified as red deer, AML 876236, from base of ditch of causewayed enclosure sealed by immediate collapse of adjacent bank at Flagstones, Southern Dorchester By-Pass, Dorset (NGR SY 899704). Coll June 1987 by M Frott and subm July 1987 by PJ Woodward, Trust for Wessex Archaeol. 
Comment (PJW): provides date for construction of segment to monument. This is rather later than date for inhumation at base of another segment; two dates make interpretation of construction and usage difficult (David 1982; Woodward 1986; Woodward \& Smith 1987).

\section{HAR-8579. W98SF272}

$$
\begin{array}{r}
4450 \pm 80 \\
\delta^{13} C=-23.6 \% \circ
\end{array}
$$

Bone (identified as maxilla of Bos longifrons) from primary fill of north ditch of Neolithic long barrow at Alington Avenue, Dorchester, Fardington, Dorset (NGR SY 702899). Coll 1985 by MJ Heaton and subm July 1987 by SM Davies, Trust for Wessex Archaeol.

Comment (SMD): paucity of datable finds (few waste flakes and flint tools) from primary fill of this funeral monument means ${ }^{14} \mathrm{C}$ is only way of placing it in complex ritual landscape round Dorchester (Davies, Stacey \& Woodward 1985).

\section{Hartlepool Church Close series}

Bone samples from Anglo-Saxon Monastery at Hartlepool Church Close, Hartlepool, Cleveland $\left(54^{\circ} 41^{\prime} 45^{\prime \prime} \mathrm{N}, 1^{\circ} 10^{\prime} 48^{\prime \prime} \mathrm{W}, \mathrm{NGR}\right.$ NZ 52853375). Coll 1985 and subm July 1987 by R Daniels, Cleveland Archaeology. Site is described in Daniels (1988).

HAR-8599. HCCA2100

$$
1320 \pm 80
$$

$\delta^{13} C=-23.1 \%$

AML 872574, from dark-brown sandy soil that occupies lowermost fill of postpit.

Comment (RD): result confirms chronologic relationship of context with Anglo-Saxon deposits.

HAR-8600. HCCBOO57

$1270 \pm 70$

AML 872578, from brown sandy soil, uppermost fill of timber palisade trench that comprises Part II of boundary complex.

Comment (RD): boundary complex has three components: I) a series of large postpits; II) a continuous timber palisade trench, and III) two large postpits set outside but parallel to I and II.

HAR-8602. HCCB0093

$1400 \pm 70$

AML 872573, from an orange-brown sandy soil, which is uppermost fill of robbed and backfilled postpit. This is component of Part I of boundary complex and is cut by Part II.

HAR-8603. HCCC0021

$1590 \pm 90$

$\delta^{13} \mathrm{C}=-23.5 \%$

AML 872576, from brown sandy soil, fill of one of two parallel gullies beyond boundary complex.

Comment (RD): result provides terminus ante quem for gully and establishes its chronologic relationship to boundary complex and timber buildings. 
HAR-8604. HCCA1920

AML 872575, from red-brown sand, backfill of posthole of timber building.

Comments (RD): result gives terminus ante quem for this timber building and establishes its chronologic relationship to boundary complex.

HAR-8608. HCCBO158

$1340 \pm 90$

$\delta^{13} \mathrm{C}=-21.2 \%$

AML 872577, from uppermost fill of robbed and backfilled postpit component of Part III of boundary complex.

Comment (RD): date gives terminus ante quem for Part III, chronologic relationship with Parts I and II as well as with timber buildings.

HAR-8647. T2PEAT

$$
\begin{array}{r}
3910 \pm 70 \\
\delta^{13} C=-30.2 \% 0
\end{array}
$$

Woody root, AML 8650254, from base of wood peat, $46 \mathrm{~cm}$ thick, exposed in bank section at Purfleet (Aveley Marshes), Thames Site 2 (NGR TQ 54457871). Coll Aug and subm Sept 1986 by P Murphy, Univ East Anglia.

Comment (PM): peat overlies palaeosol with woodland mollusk fauna and Neolithic artifacts including two polished axes.

\section{Kingsteignton, Berry Meadow series}

Charcoal samples from Kingsteignton Parish, Devon $\left(50^{\circ} 32^{\prime} 41^{\prime \prime} \mathrm{N}, 3^{\circ} 35^{\prime} 33^{\prime \prime} \mathrm{W}\right.$, NGR SX 87177295). Coll and subm July 1987 by PJ Weddell, Exeter City Mus.

\section{HAR-8664. KN85168A}

$1350 \pm 70$

$\delta^{13} \mathrm{C}=-28.3 \%$ o

AML 874381, from primary silting within Ditch 46.

Comment (PJW): ditch is from aceramic period, part of a sequence of ditch-digging activity that ended in 13th century.

HAR-8665. KN85168B

$1320 \pm 70$

$\delta^{13} \mathrm{C}=-27.5 \%$

AML 874382, from primary silting within Ditch 46, part of earliest coherent sequence of activity on site.

Comment (TP): sample was taken from ditch of aceramic period that formed part of early sequence of ditch/gully-digging activity terminating in 13th century.

HAR-8666. KN85046A

$1110 \pm 110$

$\delta^{13} \mathrm{C}=-27.6 \%$

AML 874383, from secondary infilling of Ditch 46 which forms part of earliest coherent sequence of activity on site. 
Comment (TP): ditch is part of earliest phase of sequence of ditch/gully-digging activity terminating in 13 th century.

HAR-8667. KN85046B

$1300 \pm 80$

AML 874384, from secondary infilling of Ditch 46.

$\delta^{13} \mathrm{C}=-26.5 \%$

Comment (TP): same as above.

HAR-8668. KN85141A

$1400 \pm 60$

AML 874385, from large Pit 49 cut by Ditch 46.

$\delta^{13} \mathrm{C}=-24.6 \% 0$

Comment (TP): sample was dated to provide a terminus post quem for main activity and determine early occupation.

\section{Hayes Farm series}

Charcoal samples from small barrow at Hayes Farm, Clyst Honiton, East Devon (NGR SX 99159438). Coll Feb and subm July 1987 by T Pearson, Exeter Museum.

HAR-8672. HFCH046

$1550 \pm 60$

AML 874378, ditch fill of large circular enclosure ditch.

$\delta^{13} C=-25.4 \%$

Comment (TP): ditch contains residual Roman material and no Medieval finds.

\section{HAR-8673. HFCH080}

HAR-8674. HFCH030

HAR-8675. HFCH007
$2330 \pm 90$

$\delta^{13} \mathrm{C}=-26.6 \%$

$8140 \pm 160$

$\delta^{13} \mathrm{C}=-25.0 \%$

$2700 \pm 70$

$\delta^{13} \mathrm{C}=-27.7 \%$

AML 874376, ditch fill of large ring ditch - Area A, Context 011, containing carbonized material covering postpit-type feature.

HAR-8676. HFCH066

$1910 \pm 100$

From circular enclosure.

$\delta^{13} \mathrm{C}=-27.2 \%$

General Comment: samples coll during excavations of aerial crop marks and results supplement very few radiocarbon dates currently available for Barrows/Ring ditches in southwest England.

\section{Castle Street series}

Bone samples from Castle Street, Carlisle (NGR NY39855604). Coll Aug/Sept 1981 by J Sewter and subm July 1987 by MR McCarthy, Carlisle Archaeol Unit.

HAR-8679. CSTB127

$1230 \pm 90$

$\delta^{13} \mathrm{C}=-22.9 \%$

AML 874402, identified as human vertebra, from grave oriented east-west, Period 14 of Castle 
Street stratigraphic sequence that extends from late 1st century AD to post-Medieval Period 17. Comment (MRMcC): sample is clearly post-Roman; grave cuts back-fill of well thought to be Anglo-Saxon.

\section{HAR-8770. CSTB176}

$1830 \pm 70$

$\delta^{13} \mathrm{C}=-23.4 \%$

AML 874403, animal bone, part of massive deposit (ca 2.5 million fragments) of cattle limb bones. Attributed to Period 13 of stratigraphic sequence.

General Comment: Castle Street stratigraphic sequence is well-established, up to Period 9, later Roman, but thereafter, sequence and interpretation are open to doubts.

\section{Leintwardine series}

Two samples of charcoal, ash, identified as Fraxinus sp by D Haddon-Reece, from layer sealed beneath clay and timber rampart that enclosed a small annex to Roman settlement containing a bath house at HWCM 1021, Leintwardine, Hereford and Worcester $\left(52^{\circ} 21^{\prime} 34^{\prime \prime} \mathrm{N}, 2^{\circ} 52^{\prime} 32^{\prime \prime} \mathrm{W}\right.$, NGR SO 40387390). Coll and subm 1985 by J Wills, Hereford \& Worcester Co Mus.

HAR-8677. 1021-1

HAR-8678. 1021-2

$$
\begin{array}{r}
1910 \pm 70 \\
\delta^{13} C=-26.8 \% 0 \\
2020 \pm 70 \\
\delta^{13} C=-27.9 \% \circ
\end{array}
$$

General Comment: previous excavations defined sequence of Roman military activity in northwest Herefordshire but, as yet, is poorly dated and status and character of settlement at Leintwardine are disputed (Brown, in press).

\section{Henley Wood series}

Bone samples from Henley Wood, Yatton, Avon $\left(51^{\circ} 22^{\prime} 57^{\prime \prime} \mathrm{N}, 2^{\circ} 48^{\prime} 2^{\prime \prime} \mathrm{W}\right.$, NGR ST 443652). Coll and subm Sept 1987 by L Watts.

\section{HAR-8758. GRA 5B}

$$
1590 \pm 40
$$

From double grave in area of Temple 3 ambulatory.

$$
\begin{array}{r}
\delta^{13} C=-21.6 \% 0 \\
1550 \pm 40 \\
\delta^{13} C=-21.9 \%
\end{array}
$$

HAR-8759. GRA 6

From grave in area of Temple 3 ambulatory, apparently antedates destruction of part of structure.

HAR-8760. GRA62/13

$1650 \pm 40$

From grave on southwest extremity of main group outside temple area.

$\delta^{13} \mathrm{C}=-21.1 \%$

HAR-8761. HWi264

$$
1190 \pm 90
$$

From Grave 12, below either Structure 1 or Temple 2. 
HAR-8758. GRA 5A

From double grave in area of Temple 3 ambulatory.

\section{Gnipe Howe series}

Charcoal samples from Gnipe Howe Round Barrow, Parish of Hawkser, Whitby, Yorkshire (NGR NZ 49345086). Coll Jan 1972 by TCM Brewster and subm Aug 1985 by AE Finney, East Riding Archaeol Comm.

\section{HAR-8773. GHRBQB2}

$3440 \pm 90$

Associated with Urn III and found in Quad B, resting on stones of cairn and sealed by final capping mound.

Comment (AEF): provides independent date for pot and its contents and for final sealing of mound.

\section{HAR-8774. GHRBQB3}

$3910 \pm 120$

$\delta^{13} \mathrm{C}=-28.1 \% 0$

Associated with many fragments of Urn II and found in undisturbed soil sealed by final capping of mound. Flint flakes with traces of burning and charcoal and ash deposits were also found with potsherds.

Comment (AEF): dates final capping of mound.

\section{HAR-8787. GHRBCC1}

$3500 \pm 90$

From disturbed and robbed cremation cist, in center of mound.

$$
\delta^{13} \mathrm{C}=-27.3 \%
$$

Comment (AEF): sample came from base of cist where deposits remained in situ with intact food vessel. Cremation cist appears to be earlier than later burials in urns, possibly illustrating two phases of use of Round Barrow.

\section{Kemp Howe series}

Samples from Kemp Howe, Cowlam, Yorkshire (54⒉ $21^{\prime \prime} \mathrm{N}, 0^{\circ} 58^{\prime} 47^{\prime \prime} \mathrm{W}$, NGR SE 663962). Subm Aug 1985 by AE Finney, East Riding Archaeol Comm.

HAR-8775. KHT9G5B5

$$
1290 \pm 90
$$

Bone, identified as right tibia and femur, from Grave 5, Burial 5, Anglian cemetery, Trench 9, Sec C4/P4.

\section{HAR-8776. KHT6G1B1}

$1290 \pm 70$

$\delta^{13} \mathrm{C}=-22.0 \%$

Bone, identified as right tibia and femur from Grave 1, Burial 1, Trench 6, Sec K3 in Anglian cemetery.

General Comment: these two results help clarify previous date for Grave 3, Burial 3 (HAR-6205, $1380 \pm 80$ ), which was originally thought to be too early. There are no grave goods with this series of burials to help dating. 
HAR-8778. KHLBFBT3

$4870 \pm 90$

$\delta^{13} \mathrm{C}=-27.1 \%$ postholes.

Charcoal from facade bedding trench associated with occupation debris used as packing for

Comment (AEF): facade was part of earlier phase at Kemp Howe, which included mortuary enclosure; date should be compared with that obtained for Long Barrow ditches.

\section{HAR-8779. KHASGH62}

$4330 \pm 100$

Charcoal from stone-free marl above hearth in Grubenhaus.

$\delta^{13} \mathrm{C}=-24.9 \%$

Comment (AEF): excavation of Grubenhaus provided no finds which could be used to date the building.

\section{HAR-8780. KHRBDE31}

$3730 \pm 70$

$\delta^{13} \mathrm{C}=-22.6 \%$

Antler, identified as red deer, from bottom fill of chalk rubble, rainwash and brown marl in Round Barrow ditch.

\section{Raisthorpe Manor series}

HAR-8783. RMLBFBT3

$$
\begin{array}{r}
5070 \pm 60 \\
\delta^{13} C=-26.0 \%
\end{array}
$$

Charcoal from upper level of facade bedding Trench 3, Sec E at Raisthorpe Manor Long barrow, Raisthorpe Manor, Thixendale, Nr Burdsel, North Yorkshire (NGR SE 852624). Coll March 1965 by TCM Brewster and subm Aug 1985 by AE Finney, East Riding Archaeol Comm.

Comment (AEF): dates period of use of bedding trench and related features of mortuary enclosure, pavement, etc.

\section{Seamer Moor series}

Charcoal samples from Seamer Moor Barrow 1, Nr Scarborough, North Yorkshire (NGR TA 01968617). Coll Sept 1966 by TCM Brewster and subm Aug 1985 by AE Finney.

\section{HAR-8785. SMT3SN21}

$5260 \pm 100$

From in situ red stones in vicinity of hearth.

$\delta^{13} \mathrm{C}=-26.0 \%$

Comment (AEF): hearth is sealed by mound body, thus sample dates final deposition of barrow mound.

HAR-8786. SMT3S01

$4990 \pm 90$

From shallow pit, Trench 3, Sec 0.

$\delta^{13} \mathrm{C}=-26.8 \%$

Comment (AEF): grave pit was excavated in 1934 and, as all 1934 material was destroyed in Hull bombing of 1942, this sample dates this grave pit and other three pits not found in 1966 excavation. 


\section{Shrewsbury Heritage series}

Wood, identified as alder, from Queen Anne House, Shrewsbury, Holy Cross Parish, Shropshire $\left(52^{\circ} 42^{\prime} 24^{\prime \prime} \mathrm{N}, 2^{\circ} 44^{\prime} 35^{\prime \prime} \mathrm{W}\right.$, NGR SJ498124). Coll and subm Sept 1987 by John Darlington, Birmingham Univ Field Archaeol Unit.

\section{HAR-8791. AS85F346}

AML 878299, from pile driven into clay flood deposit (1423) beneath mortar construction, Context 1403 of Structure F161 (Structure 7).

HAR-8792. AS85F273

$540 \pm 60$

AML 878297, underlying silty clay (C1685) and driven into C1435.

$$
\delta^{13} \mathrm{C}=-29.2 \% 0
$$

HAR-8793. AS85F347

$530 \pm 60$

$\delta^{13} C=-29.6 \%$ o

AML 878301, from pile driven into clay (1423) flood deposit beneath mortar construction, Context 1403, of Structure F161 (Structure 7).

HAR-8794. AS85F271

$$
\delta^{13} C=\begin{array}{r}
500 \pm 60 \\
-28.3 \%
\end{array}
$$

AML 878296, from pile underlying silty clay (C1685) and driven into $\mathrm{C} 1435$ underlying south edge of F102 wall (part of Structure 3).

HAR-8795. AS35F348

$$
\delta^{13} C=\begin{array}{r}
400 \pm 60 \\
-28.6 \% \circ
\end{array}
$$

AML 878300, from pile underlying mortar construction, Context 1403, of Structure F161.

HAR-8796. AS85F275

$620 \pm 70$

$$
\delta^{13} \mathrm{C}=-28.3 \%
$$

AML 878298, from pile underlying silty clay (C1685) driven into $\mathrm{C} 1435$, under south edge of F102.

General Comment (JD): results date two important medieval, sandstone structures for which there are few good datable contexts; results also establish chronology for pottery assemblage ante- and postdating these structures.

\section{Cannington series}

Samples of human bone from cemetery at Cannington, Somerset. Coll 1962-3 by PA Rahtz and subm Aug 1984 by PA Rahtz, S Hirst and S Wright.

HAR-8806. 407 $720 \pm 100$

From grave with late grave goods.

$\delta^{13} \mathrm{C}=-21.8 \% 0$ 
HAR-8807

$$
\begin{array}{r}
1060 \pm 110 \\
\delta^{13} C=-19.5 \% \circ
\end{array}
$$

Identified as young child, from grave with late grave goods, including 7 th/8th century brooch.

\section{Helman Tor series}

Charcoal from Middle Neolithic settlement site at Helman Tor, Parish of Lanlivery, Lostwithiel, Cornwall $\left(50^{\circ} 24^{\prime} 49^{\prime \prime} \mathrm{N}, 4^{\circ} 43^{\prime} 11^{\prime \prime} \mathrm{W}\right.$, NGR SX 068607). Coll Aug 1986 and subm June 1987 by R Mercer, Univ Edinburgh.

HAR-8818. HT8659

$4880 \pm 120$

AML 874387, from posthole of Neolithic structure.

$$
\delta^{13} \mathrm{C}=-28.9 \%
$$

HAR-8819. HT86L6

$4520 \pm 60$

$\delta^{13} \mathrm{C}=-26.8 \%$

AML 874388, from Layer 6, dark-black, soft-textured matrix rich in Neolithic finds (midden). Comment (RM): allows internal chronologic comparison of midden and structure built over it.

\section{HAR-8820. HT86604}

$4490 \pm 70$

$$
\delta^{13} \mathrm{C}=-27.9 \%
$$

AML 874389, from pit-hearth within occupation surface close to concentration of postpits.

Comment (RM): relates to latest phase of activity on terrace and gives a terminus ante quem for construction of enclosure wall.

HAR-8821. HT8660B

AML 874390, from same context as above.

Comment (RM): as above. Dates period of Neolithic occupation associated with structure and superimposed on midden.

HAR-8822. HT86103A

$4780 \pm 70$

$\delta^{13} C=-26.7 \%$ 。 terrace.

AML 874391, from pit-hearth cut through Layer 6, relating to latest phase of activity on

Comment (RM): establishes terminus ante quem for construction of Neolithic enclosure wall.

HAR-8823. HT86103B

$4750 \pm 70$

AML 874392, same as above.

$$
\delta^{13} \mathrm{C}=-27.9 \%
$$

General Comment: samples date this Middle Neolithic settlement site and allow comparison with very similar site dated ca $3000-2700$ BC at Carn Brea, Illogan, Cornwall (Mercer 1986). 
HAR-8875. LINDPODZ

$4980 \pm 70$

$\delta^{13} \mathrm{C}=-27.8 \%$

Charcoal and soil, AML 876165, from sand island within peat bog at Lindow Moss, Cheshire (NGR 820805). Coll and subm Oct 1987 by M Canti.

\section{HAR-8876. D2/CON3}

$4020 \pm 70$

$\delta^{13} \mathrm{C}=-26.1 \%$

Charcoal, AML 878285 (identified as oak Quercus sp) from spread of charcoal on palaeosol over pale-gray silty fine sand exposed on foreshore, sealed by up to $140 \mathrm{~cm}$ of estuarine clays at Dovercourt Bay, Site 2, Essex (51 $55^{\circ} 5^{\prime \prime} \mathrm{N}, 1^{\circ} 15^{\prime} 56^{\prime \prime}$ E, NGR TM 24552950$)$. Coll July and subm Oct 1987 by P Murphy, Univ East Anglia.

Comment (PM): similar charcoal spreads in comparable stratigraphic situations from Blackwater Estuary have yielded dates in the range of $2740-2040 \mathrm{BC}$ and may represent Neolithic woodland clearances. Flintwork and pottery from Dovercourt site suggested similar activity and date confirms this.

Colne Site 1 series

HAR-8877. COL1/7

$760 \pm 70$

$\delta^{13} \mathrm{C}=-27.8 \% 0$

Wood, AML 878286, from wooden structure on foreshore in estuarine muds at Alresford, Essex $\left(51^{\circ} 50^{\prime} 17^{\prime \prime} \mathrm{N}, 0^{\circ} 59^{\prime} 17^{\prime \prime} \mathrm{E}, \mathrm{NGR}\right.$ TM 0582 1978). Coll and subm Oct 1987 by P Murphy.

Comment (PM): riverbank structure originally was assumed to be Roman.

HAR-8878. B3/182

$2790 \pm 70$

$\delta^{13} \mathrm{C}=-27.6 \%$

AML 878287, from small wooden structure on lower foreshore in estuarine clays overlying Mesolithic site at Maylandsea, Essex $\left(51^{\circ} 42^{\prime} 14^{\prime \prime} \mathrm{N}, 0^{\circ} 46^{\prime} 7^{\prime \prime} \mathrm{E}\right.$, NGR TL 9128 0427). Coll July and subm Oct 1987 by P Murphy.

Comment (PM): low elevation of structure suggested Bronze Age date or earlier, which date confirms.

HAR-8879. B18/192

$2850 \pm 70$

$\delta^{13} \mathrm{C}=-25.8 \%$ 。

AML 878288, from wooden structure on foreshore in estuarine clays at Tollesbury, Essex (51 $44^{\prime} 14^{\prime \prime} \mathrm{N}, 0^{\circ} 48^{\prime} 45^{\prime \prime} \mathrm{E}, \mathrm{NGR}$ TL 9418 0809). Coll July and subm Oct 1987.

Comment (PM): sample was dated to establish whether complex is late Bronze Age or whether this is multi-component site. Determination suggests former.

\section{Easton Lane series}

HAR-8882. ELI83F

$3800 \pm 70$

$\delta^{13} \mathrm{C}=-24.4 \%$

Bone, AML 833181, from posthole of small oval post-built structure with large closely spaced postholes at Easton Lane Interchange, Winchester, Hants $\left(51^{\circ} 4^{\prime} 16^{\prime \prime} \mathrm{N}, 1^{\circ} 17^{\prime} 26^{\prime \prime} \mathrm{W}\right.$, NGR SU 
497305). Coll and subm Sept 1983 by PJ Fasham, Trust for Wessex Archaeol.

Comment (PJF): dates associated cultural material and general site ceramic sequence.

\section{Danby Rigg series}

Four samples of charcoal in silt from Danby Rigg, North Yorkshire (NZ 705055), a promontory defended by cross-ridge dykes and covered with a large cairn field. Samples coll July 1986 by SD Carter and AF Harding and subm Feb 1988 by AF Harding, Univ Durham.

HAR-8908. TD/5

$$
\begin{array}{r}
1140 \pm 60 \\
\delta^{13} C=-30.0 \% 0
\end{array}
$$

Dark layer (327) with small charcoal pieces overlying orange and gray clay and ca $1.10 \mathrm{~m}$ below surface in north ditch.

HAR-8909. TD/6

$1510 \pm 80$

Same as above.

$\delta^{13} \mathrm{C}=-30.2 \%$

HAR-8910. TD/23

$1120 \pm 80$

$\delta^{13} \mathrm{C}=-29.5 \%$

Thin layer $0.25 \mathrm{~m}$ above base of south (outer) ditch, part of triple dyke system.

HAR-8911. TD/7

$990 \pm 60$

Same as above.

$\delta^{13} \mathrm{C}=-28.4 \%$

General Comment: datable monuments at site are Bronze Age and dyke system had been expected to be contemporary rather than early Medieval as shown by dates. Samples were low in ditch fill and presumably date early stage in its life.

\section{Sutton Common series}

Wood and carbonized seeds from Sutton Common, Norton Parish, Doncaster District, South Yorkshire $\left(53^{\circ} 36^{\prime} 8^{\prime \prime} \mathrm{N}, 1^{\circ} 8^{\prime} 57^{\prime \prime} \mathrm{W}\right.$, NGR SE 563121). Coll and subm 1987 by Bob Sydes.

HAR-8914. SC108C03

Wood, identified as roundwood, from part of timber framework or raft which includes re-used structural timbers, possibly associated with stakes in ditch.

Comment (BS): stratigraphically later than bank and ditch cut.

HAR-8915. SC059C01

$2260 \pm 70$

$\delta^{13} \mathrm{C}=-29.5 \%$

Wood, identified as roundwood, from first organic accumulation in the ditch overlying natural clay at base of ditch.

Comment (BS): roundwood is directly related to framework of poles and logs cut from coppice stools. Framework represents use, not necessarily first, of ditch. Establishes terminus ante quem for ditch and bank. 
HAR-8917. SC057C04

Carbonized seeds, identified as spelt, some emmer, AML 881217, from substantial dump within ditch fill 057, tipped from west side of ditch.

Comment (BS): results of this environmental sample identify aquatic and waterside plants and a dung beetle. Sample is stratigraphically later than 059 (framework) and gives terminus ante quem for burial of wooden framework (SC059C01) and date for later use of enclosure.

\section{Binsey series}

Bone samples from sequence of major ditches at Binsey in Thames floodplain west of Oxford $\left(51^{\circ} 46^{\prime} 2^{\prime \prime} \mathrm{N}, 1^{\circ} 17^{\prime} 44^{\prime \prime} \mathrm{W}, \mathrm{NGR}\right.$ SP 486 079). Coll and subm by J Blair, The Queen's Coll, Oxford.

\section{HAR-8935. BYC 3}

$590 \pm 90$

$\delta^{13} \mathrm{C}=-22.8 \%$

Identified as sheep and dog by B Leverton, AML 878265, from gravel bank overlying fill of whole sequence of major ditches at Binsey.

\section{Albany Road series}

HAR-8979. ALB1

$3720 \pm 140$

$\delta^{13} \mathrm{C}=-30.2 \%$

Wood, AML 858578 (identified as Alnus sp and Alnus sp/Corylus avellana) from base of silted-up former channel of River Exe at Exeter, Devon ( $50^{\circ} 42^{\prime} 55^{\prime \prime} \mathrm{N}, 3^{\circ} 32^{\prime} 3^{\prime \prime} \mathrm{W}, \mathrm{NGR}$ SX 917918$)$. Coll May 1984 by V Straker and C Henderson and subm Sept 1985 by V Straker.

\section{REFERENCES}

ApSimon, A, Donovan, DT and Taylor, H 1961 The stratigraphy and archaeology of the late glacial and post glacial deposits at Brean Down, Somerset. Univ Bristol Spelaeol Soc Proc 9: 67-136.

Bell, M 1986 Brean Down. Current Archaeol 102: 218-221. 1990 Brean Down excavations 1983-1987. English Heritage Archaeol report 15. Hist Bldgs Monuments Comm (England).

Boddington, A and Cadman, G 1981 Raunds: An interim rept on excavations 1977-1980. Anglo-Saxon studies in Archaeol and Hist 2. Brit Archaeol Rept, Br ser 92.

Brown, DL, in press, The Roman small town at Leintwardine: Excavations and other fieldwork, 1971-89. Woolhope Nature Field Club Trans

Brown, N 1988 A Late Bronze Age enclosure at Lofts Farm, Essex. Prehist Soc Proc 54: 249-302.

Cadman, GE 1983 Raunds Furnells 1977-1983, an excavation summary. Medieval Archaeol 27: 107-122.

Carr, RD, Tester, A and Murphy, P 1988 The Middle Saxon settlement at Stanch Meadow, Brandon. Antiquity 62(235): 371-377.

Chowne, P, Girling, M and Greig, JRA 1986 Excavations at an Iron Age defended enclosure at Tattershall Thorpe, Lincs. Prehist Soc Proc 52:

Clay, P and Salisbury, CR 1990 A Norman Mill Dam and other sites at Hemington Field, Castle Donington. Archaeol Jour Dacre, M and Ellison, E 1981 A Bronze Age urn cemetery at Kimpton. Prehist Soc Proc 47: 147-203.

Daniels, R 1988 The Anglo-Saxon Monastery at Church Close, Hartlepool. Archaeol Jour 145: 202.

David, A 1982 Geophysics Survey for the Dorchester By-Pass. AML rept G2/82, Hist Bldgs Monuments Comm (England).

Davies, SM, Stacey, LC and Woodward, PJ 1985 Excavations at Alington Avenue, Fordington, Dorchester, 1984/85: Interim report. Dorset Nat'l Hist Soc Proc 107: 101-110.

Dent, JS 1983 Summary of the excavations in Garton and Wetwang Slack. East Riding Archaeologist 7: 1-12. 
Durham, B 1977 Archaeological investigations in St Aldate's, Oxford. Oxoniensia 42: 83-203. 1984 The Thames crossing at Oxford. Oxoniensia 49: 57-100.

Evans, C 1986 The Upper Delphs. Fenland Research 3.

Evans, C and Serjeantson, D 1988 The backwater economy of a fen-edge community in the Iron Age: The Upper Delphs, Haddenham. Antiquity 62: 360-370.

French, CAI and Pryor, FMM, in press, The Southwest Fen Dyke Survey, 1982-6. East Anglia Archaeology monograph. Mercer, RJ 1980 Hambledon Hill, a Neolithic landscape. Edinburgh, Edinburgh Univ Press.

Mercer, R 1986 Excavation of a Neolithic enclosure at Helman Tor, Lanlivery, Cornwall, 1986. Interim rept. Project Paper no. 4, Dept Archaeol, Univ Edinburgh.

Otlet, RL 1979 An assessment of errors in liquid scintillation counting. In Berger, R and Suess HE, eds, Radiocarbon dating, Internatl ${ }^{14} \mathrm{C}$ conf, 9th, Proc: Berkeley, Univ California Press: 256-267.

Otlet, RL and Walker, AJ 1979 Harwell radiocarbon measurements III. Radiocarbon 21(3): 358-360.

Phillips P 1989 Archaeology and landscape studies in North Lincolnshire. Brit Archaeol Rept, Br ser 208 (ii): 169-171.

Salisbury, CR 1984 Ancient courses of the River Trent at Colwick, Nottingham. The Mercian Geologist 9(4): 189-207. 1988 A Saxon and Norman fish weir at Colwick, Nottinghamshire. In Aston M, ed, Medieval fish, fisheries and fishponds in England. Brit Archaeol Rept, Br ser 182 (ii): 329-351.

Taylor, H and Taylor, EE 1949 An early Beaker burial? at Brean Down near Weston-super-Mare. Univ Bristol Spelaeol Soc Proc 6: 88-93.

Walker, AJ, Williams, N and Otlet, RL 1990 Harwell radiocarbon measurements VIII. Radiocarbon 32(2): 165-196.

Wilkinson, TJ and Murphy, P 1986 The Hullbridge Basin Survey. Interim rept no. 6. Essex County Council, Chelmsford. 1988 The Hullbridge Basin Survey. Interim rept no. 8. Essex County Council, Chelmsford.

Woodward, PJ 1986 Observations along the Wessex Water Authority supply line: Alington Avenue and Mount Pleasant. Dorset Natl Hist and Archaeol Soc Proc 108: 177-180.

Woodward, PJ and Smith, RJC 1987 Survey and excavation along the route of the southern Dorchester by-pass, 1986-7 - An interim note. Dorset Natl Hist Soc Proc 109: 79-89. 